\title{
Biomarkers of iron metabolism in chronic kidney disease
}

\author{
Glogowski Tomasz $^{1} \cdot$ Wojtaszek Ewa $^{1} \cdot$ Malyszko Jolanta ${ }^{1}[$
}

Received: 11 May 2020 / Accepted: 21 September 2020 / Published online: 6 October 2020

(c) The Author(s) 2020

\begin{abstract}
Iron is the most abundant transition metal in the human body and an essential element required for growth and survival. Our understanding of the molecular control of iron metabolism has increased dramatically over the past 20 years due to the discovery of hepcidin, which regulates the uptake of dietary iron and its mobilization from macrophages and hepatic stores. Anemia and iron deficiency are common in chronic kidney disease. The pathogenesis of anemia of chronic kidney disease is multifactorial. Correction of anemia requires two main treatment strategies: increased stimulation of erythropoiesis, and maintenance of an adequate iron supply to the bone marrow. However, there are still many uncertainties in regard to iron metabolism in patients with chronic kidney disease and in renal replacement therapy. The aim of this review was to summarize the current knowledge on iron metabolism in this population, including new biomarkers of iron status. There is an area of uncertainty regarding diagnostic utility of both erythroferrone (ERFE) and hepcidin in end-stage renal disease (ESRD) patients. Higher concentration of hepcidin in oligoanuric patients may reflect decreased renal clearance. Furthermore, the hepcidin-lowering effect of ERFE in ESRD patients treated with erythropoiesis-stimulating agents (ESAs) may be blunted by underlying inflammation and concomitant iron treatment. Thus, future studies should validate the use of ERFE as a biomarker of erythropoiesis and predictor of response to iron and ESA therapy in dialysis-dependent patients.
\end{abstract}

Keywords Iron metabolism $\cdot$ Hepcidin $\cdot$ Chronic kidney disease

\section{Introduction}

According to World Health Organization (WHO), anemia is defined as a hemoglobin concentration below $13 \mathrm{~g} / \mathrm{dl}$ for adult males and below $12 \mathrm{~g} / \mathrm{dl}$ for non-pregnant women [1]. The most common cause of anemia worldwide is iron deficiency, while anemia of inflammation is the second most prevalent type. Prevalence of anemia in patients with chronic kidney disease (CKD) increases in more advanced stages of CKD, affecting the majority of stage G4 patients (eGFR of 15 to $30 \mathrm{ml} / \mathrm{min}$ ) [2,3]. There are several underlying factors contributing to anemia in this population-relative erythropoietin deficiency, iron deficiency (both absolute and functional), impaired hepcidin clearance, shorter erythrocyte lifespan, and nutritional deficiencies (folic acid and vitamin B12, among others). CKD stage G5 patients on hemodialysis

Malyszko Jolanta

jolmal@poczta.onet.pl

1 Department of Nephrology, Dialysis and Internal Medicine, Medical University of Warsaw, ul. Banacha 1a, 02-097 Warsaw, Poland
(HD) have additional iron loss (up to $3 \mathrm{~g}$ per year) [4] as a consequence of chronic bleeding, repeated phlebotomy (venipuncture) and blood lost in the dialyzer and the lines. Furthermore, both HD and peritoneal dialysis (PD) patients are likely to develop chronic subclinical inflammation as a result of exposure to dialyzer membrane and drains and nonbiocompatible dialysis fluid, respectively. Anemia in CKD patients leads to reduced quality of life and cardiovascular performance, cognitive impairment, increased rate of hospitalizations and increased mortality [4]. Additionally, anemia may contribute to accelerated progression to end-stage renal disease (ESRD) [5].

\section{Iron metabolism}

Iron is one of the essential elements in all living organisms. Approximately $71 \%$ of total body iron is found in hemoglobin and myoglobin in ferrous state $\left(\mathrm{Fe}^{2+}\right) .25 \%$ is contained in storage proteins, ferritin and hemosiderin, in ferric state $\left(\mathrm{Fe}^{3+}\right)$. The unique properties of iron, which can serve as both acceptor and donor of electrons, are responsible for 
its biologic functions but at the same time determine its toxicity. Excess iron may promote formation of reactive oxygen species (ROS) and lead to oxidative stress via damage to DNA, proteins and lipid membranes (Casu C Hepcidin agonists as therapeutic tools). As a heme cofactor, hemoglobin is responsible for transport of oxygen. Furthermore, iron is one of the compounds of catalase, peroxidase, cytochromes and other enzymes $[6,7]$. Daily iron requirements amount to approximately $25-30 \mathrm{mg}[8,9]$, while iron loss (resulting from, e.g. menstruation, enterocyte and epidermal desquamation, with traces of iron also found in sweat and urine) constitutes 1-2 mg per day. There is no active mechanism that enables the elimination of iron. As a result, to maintain adequate iron balance, intestinal absorption of the element must cover daily iron loss. Healthy balanced diet provides approximately $10-20 \mathrm{mg}$ of iron, of which $1-4 \mathrm{mg}$ is absorbed [6, 10]. Absorption of ferrous iron $\left(\mathrm{Fe}^{2+}\right)$ takes place in the apical enterocytes of the duodenum with the aid of the Divalent Metal Transporter 1 (DMT1), while heme can also be absorbed via Heme Carrier Protein 1 (HCP1) [4, 7]. Ferric iron $\left(\mathrm{Fe}^{3+}\right)$ is not easily absorbed; therefore, the reduction of $\mathrm{Fe}^{3+}$ to $\mathrm{Fe}^{2+}$ is required. This process is enabled by duodenal cytochrome b-like ferrireductase enzyme (Dcytb). Absorbed iron can be stored in the enterocytes in ferritin-bound form (and usually lost as a result of enterocyte desquamation) or transported to the plasma via ferroportin (FPN1; also found in macrophages, hepatocytes and the placenta), where it binds to transferrin, which requires prior iron oxidation by hephaestin, a multicopper ferroxidase present on the basolateral membrane of the enterocyte. Transferrin, the essential iron-binding protein produced in the liver, can reversibly bind two ferric ions, thus changing its conformation to holotransferrin. Usually approximately $30-40 \%$ of transferrin molecules are saturated with iron, which means that the majority of transferrin in the plasma has conformation called apotransferrin and can buffer excess iron, if necessary. Circulating holotransferrin can be taken up by cells which have increased iron demands, e.g. erythrocyte precursors, via binding to transferrin receptor 1 (TfR1). Holotransferrin enters the cytoplasm by means of endocytosis and as a result of $\mathrm{pH}$-associated change in conformation, releases iron ions. Ferric iron is once again reduced to $\mathrm{Fe}^{2+}$ and crosses endosomal barrier via DMT1 and is ready to be incorporated into various enzymes or storage proteins (Fig. 1).

\section{Role of hepcidin}

Hepcidin, a 25-amino acid polypeptide discovered in 2000, is one of the key elements of systemic iron metabolism [11]. Hepcidin is a hormone produced predominantly in the hepatocytes and released into the plasma. It binds to ferroportin present in the cell membrane of enterocytes and macrophages and via tyrosine phosphorylation leads to internalization of ferroportin and eventually its degradation in the lysosomes. As a result, iron transport from the duodenum to the blood circulation is diminished, iron release from macrophages and hepatocytes is blocked and, consequently, iron recirculation is impaired and serum iron levels decrease [6]. Hepcidin production increases in response to iron overload, inflammation or infection, while its synthesis is diminished as a result of iron deficiency, increased erythropoiesis and hypoxia. Hepcidin expression is regulated by numerous proteins-bone morphogenetic protein-6 (BMP-6), hemojuvelin (HJV), human hemochromatosis protein (HFE), transferrin receptors TfR 1 and TfR2, among others. They are influenced by both liver iron stores and circulatory iron in the form of iron-bound transferrin (holotransferrin) [12, 13]. Increased iron levels stimulate production of BMP-6, which binds to its receptor on the surface of hepatocyte and forms a complex with HJV (a membrane-bound co-receptor). This process induces SMAD (small mothers of decapentaplegic) phosphorylation pathway, leading to increased expression of hepcidin genes. HFE forms a complex with TfR and beta-2-microglobulin and TfR2, which in a notyet-known fashion induces transcription of hepcidin genes. Mutations in the abovementioned proteins cause hereditary hemochromatosis, which manifests itself in hepcidin deficiency and iron overload [14]. Erythropoiesis stimulating factors affect hepcidin synthesis as well-for example, in the event of excessive erythropoiesis, erythropoietin (via binding with EPO receptor on the surface of hepatocytes) and growth differentiation factor 15 (GDF-15) decrease expression of hepcidin [15]. Furthermore, increased erythropoiesis is associated with elevated concentration of soluble transferrin receptor (sTfR), which is cleaved from transmembrane transferrin receptor expressed mainly in cells with high iron demands [15].

Recently, a hormone erythroferrone (ERFE) has been linked with erythropoiesis and iron balance. ERFE is synthesized in erythroblasts in response to increased erythropoiesis and it suppresses transcription of hepcidin in hepatocytes and thus increases iron availability in conditions associated with greater iron demand [16]. In murine models, ERFE deficiency is associated with mild hypochromic anemia and delayed hepcidin suppression following hemorrhage or EPO injection, while in certain conditions with ineffective erythropoiesis, such as $\beta$-thalassemia, ERFE concentrations were significantly increased [17] (Fig. 2).

Under hypoxic conditions, oxygen deficiency leads to diminished transcription of hepcidin genes (and consequently decreased production of hepcidin) via hypoxiainducible factors (HIF-1 $\alpha$, HIF-2 $\alpha$ ) [18]. HIFs activate the expression of matriptase-2 (also known as the transmembrane protease, serine 6; TMPRSS6), which cleaves HJV 
Fig. 1 Iron absorption and metabolism. Dcytb duodenal cytochrome b-like ferrireductase, $D M T 1$ divalent metal transporter $1, H C P 1$ heme carrier protein 1, FPN1 ferroportin, $T f R l$ transferrin receptor 1

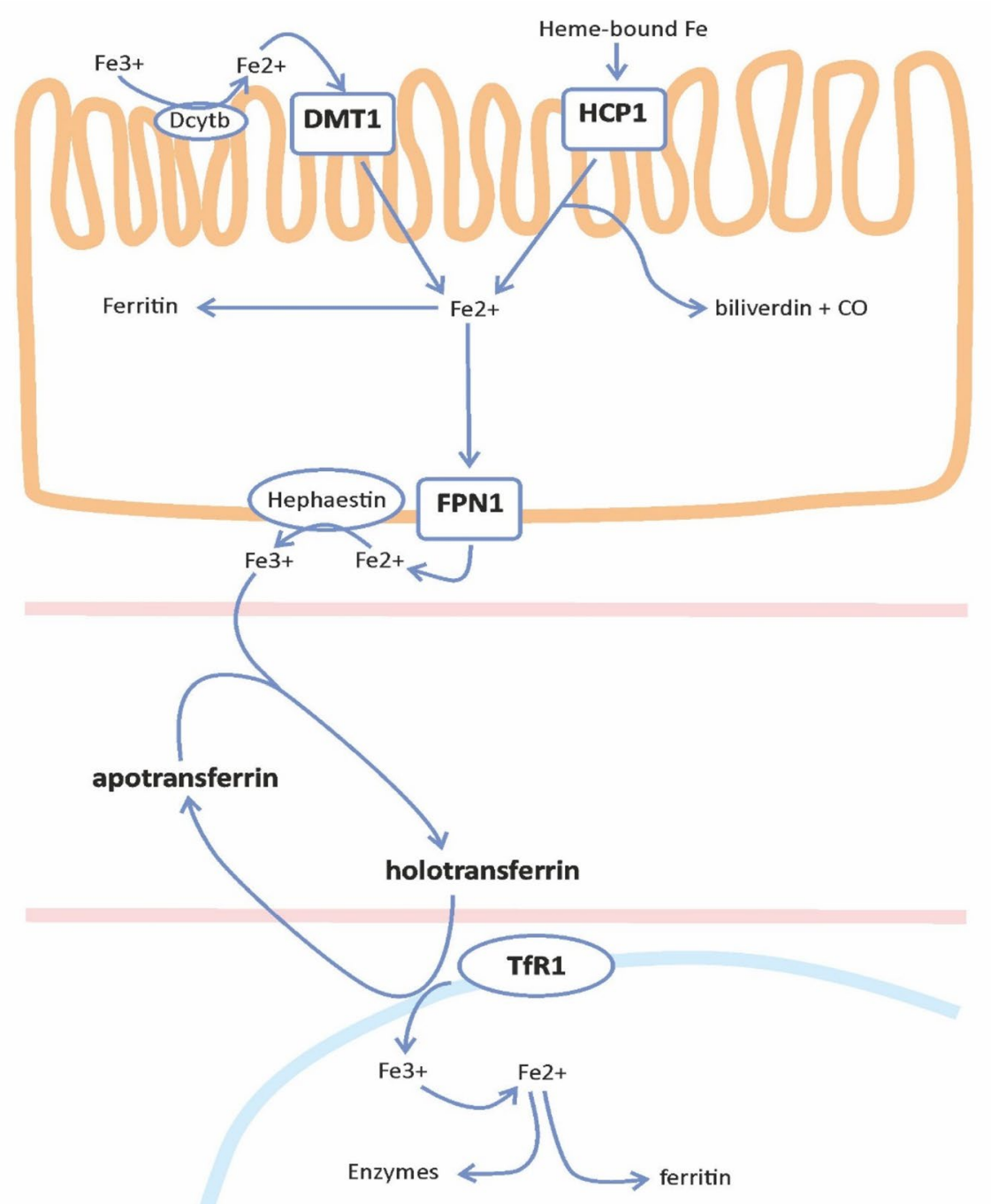

from the HFE/TfR2/HJV complex, decreasing hepcidin synthesis [19]. Recently, it has been suggested that iron affects the release of fibroblast growth factor 23 (FGF-23) - a marker of increased risk of cardiovascular incidents, especially in CKD patients [20-23]. However, outcomes from clinical studies have so far been inconsistent; therefore, the impact of iron on FGF23 is unclear [24-26]. Finally, studies in humans revealed that hepcidin is one of the acutephase proteins. It was proved that IL- $1 \alpha$, IL- $1 \beta$, as well as IL-6 stimulate its expression $[11,27]$ via activation of the STAT3 transcription factor [28] - a mechanism responsible for iron restriction in the event of bacterial infection. Furthermore, mice with hepcidin antimicrobial peptide (HAMP) gene overexpression were affected by inflammation-related anemia of chronic diseases [29]. Conditions associated with inflammation (e.g. chronic kidney disease) lead to hepcidin-mediated iron sequestration in the reticuloendothelial cells and, consequently, decrease iron concentration in the system. At the same time, iron distribution becomes impaired; hence, iron availability for the synthesis of hemoglobin is reduced. As a result, anemia of inflammation (anemia of chronic diseases) develops [30]. In addition, in the setting of inflammation, patients can have high ferritin levels, low TSAT, and increased iron stores but still experience restricted erythropoiesis resulting from "reticuloendothelial blockade" [5]. Moreover, functional iron deficiency, a state of inadequate delivery of iron to the bone marrow in the setting of adequate iron stores, is caused by impaired iron mobilization (from the reticuloendothelial system [RES]) and/or increased bone marrow iron demand (as might be secondary to reduced red cell life span and/or erythropoiesis-stimulating agents [ESA] use) [31]. Proinflammatory 


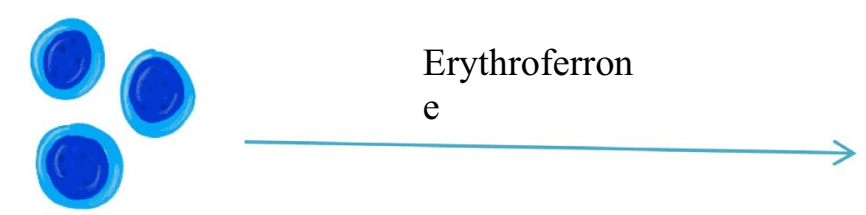

Erythroblast

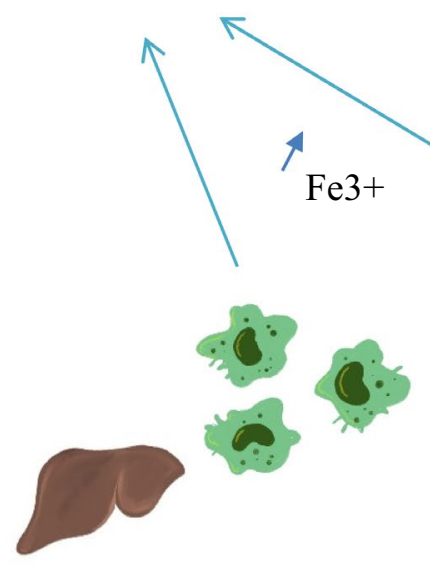

Under
Spleen and
liver

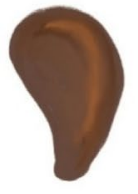

hypoxic

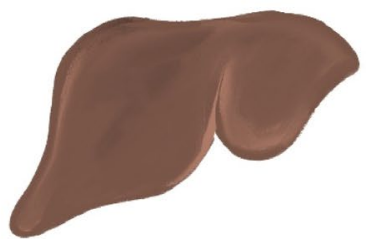

Liver
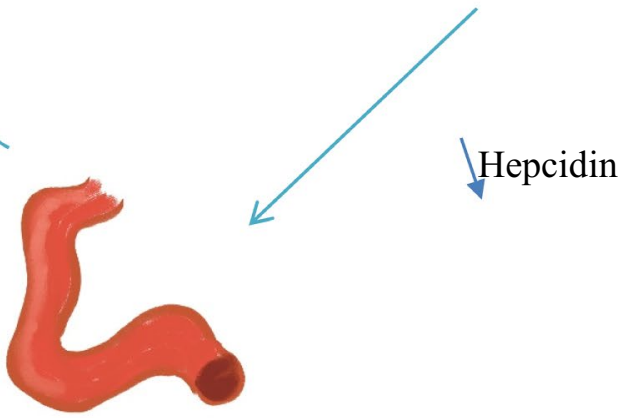

Duodenu

$\mathrm{m}$

conditions, oxygen deficiency

Fig. 2 Increased erythroferrone production by erythroblasts suppresses hepcidin synthesis in the liver. Low hepcidin concentration increases iron availability for erythropoiesis by enhancing iron absorption in the duodenum and iron release from macrophages in the liver and the spleen

cytokines are responsible for various processes typical of anemia of chronic diseases-they suppress erythropoiesis in the bone marrow, impair the production of erythropoietin (EPO) $[31,32]$ and increase the rate of erythrophagocytosis leading to shorter erythrocyte lifespan [6]. Moreover, in the event of chronic kidney disease the clearance of hepcidin is diminished and, as a result, its plasma concentration increases.

\section{Assessment of iron status}

Understanding the dysregulation of iron metabolism is essential for the precise assessment, predicting treatment response as well as effective and safe treatment of anemia of chronic kidney disease. A number of biomarkers of iron status in chronic kidney disease have been used in clinical settings. However, many of them are influenced by renal failure alone and concomitant inflammation. Due to these confounding effects on the interpretation of most of biomarkers, the assessment of iron status in chronic kidney disease is still a challenge $[5,33,34]$.

Serum iron, transferrin (Tf), total iron binding capacity (TIBC, calculated as $\mathrm{Tf} \times 1389$ ), transferrin saturation (TSAT, calculated serum iron/total iron binding capacity $\times 100)$ and serum ferritin are traditionally used in the evaluation of iron status and the diagnosis of iron deficiency anemia (IDA) [35]. In general population, decreased serum ferritin $(<15 \mathrm{ng} / \mathrm{ml})$ and decreased TSAT $(<16 \%)$ are used for diagnosis of iron deficiency (ID) and iron deficiency anemia (IDA) in individuals without concomitant inflammation [35]. The international guidelines for the management of IDA in CKD use the same diagnostic tests; however, they recommend different cutoff levels of serum ferritin and TSAT for the diagnosis and initiation of iron supplementation. Some guidelines recommend higher cutoff levels of TSAT $(\leq 30 \%)$ and serum ferritin $(\leq 200-500 \mathrm{ng} /$ $\mathrm{ml})[36,37]$, while others, lower TSAT $<20 \%$ and serum ferritin $<100 \mathrm{ng} / \mathrm{ml}[38-40]$. The reason for the difference remains unclear, but at least in part, it may reflect the consideration of the influence of inflammation on iron metabolism disorders in CKD and the distinct prevalence of inflammation severity between patient populations in different countries. Regardless of the values adopted, the numerous limitations of these diagnostic tools in the assessment of iron stores in the storage and functional pools, and in predicting the response to treatment should be emphasized. The traditional cutoffs of TSAT at $\leq 20 \%$ and serum ferritin $\leq 100 \mathrm{ng} / \mathrm{ml}$ have low sensitivity in iron deficiency detection. In Stancu et al.'s [41] study, these indices identified only $17 \%$ patients with CKD stage $3-5$ as iron deficient whereas $50 \%$ prove to be iron deficient based on bone 
marrow iron staining. Another limitation of these biomarkers is scant ability to differentiate between absolute and functional iron deficiency. It is assumed that low TSAT combined with normal or elevated serum ferritin level is diagnostic of functional iron deficiency [42]. However, if functional iron deficiency results of supply/demand mismatch, for example, during treatment with ESA, iron may transfer from transferrin faster than it can be mobilized from the iron stores, resulted in TSAT decrease [43].

The changes occurring in iron metabolism in CKD patients are different from those observed in iron deficiency in general population reflecting the effect of inflammation being a part of uremic state. With the progression of kidney disease, the production of transferrin in the liver is reduced, and in advanced stages of CKD, transferrin levels are reduced by $30 \%[44,45]$. As an acute-phase reactant, TIBC progressively decreases with kidney disease progression, and it leads to higher TSAT levels independent of iron status (13) and reduces its credibility as a measure of iron status and a threshold for initiating iron therapy in CKD patients [46]. In the meanwhile, in the majority of patients with stage 3-5 CKD, TSAT $<20 \%$ may correspond to serum iron levels below the lower limit and be indicative of iron deficiency [47]. It is postulated that more important parameter to assess iron status and prevent iron-limited erythropoiesis in CKD patients is iron concentration rather than TSAT. In recently published review, to avoid iron deficiency, target serum iron of $60 \mu \mathrm{g} / \mathrm{dl}$ was assumed, which corresponds to TSAT of $20 \%$ in CKD stage 3, and $22-25 \%$ in stage 4 or 5 . It is established in clinical practice that serum iron is the more predictive index of iron sufficiency excluding iron-deficient erythropoiesis in hemodialysis patients [48].

Ferritin as an acute-phase reactant is frequently elevated in CKD patients irrespective of their iron stores [49]. Increased serum ferritin levels are the result of systemic inflammation and correlate positively with the severity of inflammation [50, 51]. Thus, the interpretation of serum ferritin is complicated by concomitant inflammation [35, 45]. Under minor inflammation, the specificity of low serum ferritin concentration of absolute iron deficiency diagnosis is high [35, 52], but if apparent inflammation is present, normal or elevated ferritin levels cannot exclude iron deficiency in CKD [35, 52]. Inflammation may also reduce the predictive value of serum ferritin for the response to iron supplementation. The baseline ferritin level may be predictive of the response to oral [53] and intravenous [54] iron treatment only in patients with minor inflammation expressed as low CRP level. Under concomitant inflammation, ferritin loses its predictive value of the response to iron therapy. Moreover, in highly inflamed patients, not only ferritin but also other biomarkers of iron metabolism (TSAT, $\mathrm{CHr}$, or sTfR) lose their value in predicting treatment response [55-57]. In these patients, the values of CRP, but not indices of iron status may be predictive of the response to iron supplementation $[55,57]$, and there is no correction factor that could applied in estimation of iron stores depending on ferritin concentration [48].

The limitations of traditional biomarkers of iron metabolism and the response to treatment created the need to search for alternative diagnostic tools for iron management in CKD patients.

Soluble transferrin receptor (sTfR) is produced by proteolysis of the membrane transferrin receptor (TfR). Its release into circulation is increased in the setting of iron deficiency; hence, sTfR has been evaluated as a potential biomarker of iron deficiency. Soluble TfR is not an acute-phase reactant and is less influenced by inflammation than other iron metabolism indices [58]. The serum concentration of sTfR is increased in hemodialysis patients with iron deficiency and correlate inversely with iron available for erythropoiesis; however, it is not able to detect occult iron deficiency [42, $59,60]$. Unfortunately, the interpretation is confounded by the use of ESA [35, 45], and appears to represent erythropoietic activity rather than iron deficiency $[42,59,60]$. The index of sTfR to $\log _{10}$ ferritin has better than TSAT and ferritin predictive value of iron supplementation responsiveness in hemodialysis patients [61]. The limitations of widespread measurement of sTfR include not-established standard cutoffs, costs and availability in the laboratory.

Other biomarkers of iron status include reticulocyte hemoglobin content $(\mathrm{CHr})$ and percentage of hypochromic red blood cells (\%Hypo). $\mathrm{CHr}$ provides an expression of iron availability for erythropoiesis within 3-4 days [35, 45] and $\mathrm{CHr}<27.2 \mathrm{pg}$ is diagnostic for iron deficiency [35]. \% Hypo measures the concentration of hemoglobin in red blood cells (RBC), which reflects absolute amount of hemoglobin and the RBC size $[35,45]$ and serves as a sensitive marker of iron deficiency $[35,45]$ and iron status changes in the long-term assessment [35, 45]. Both these biomarkers are influenced by inflammation [62, 63]. Nevertheless, $\mathrm{CHr}$ and \%Hypo have, compared to TSAT and serum ferritin, better sensitivity and specificity to predict iron deficiency in late stages of CKD [48]. CHr and \%Hypo are predictive of iron responsiveness $[64,65]$ with at least similar test accuracy compared with traditional biomarkers in predicting hemoglobin increase to intravenous iron administration [66]. It needs to be highlighted that during iron supplementation the temporal changes of $\mathrm{CHr}$ and \%Hypo differs- $\mathrm{CHr}$ can normalize within 2-3 days, whereas \%Hypo can take even months [48]. Unfortunately, both measurements are limited by testing requirements. \% Hypo must be tested on fresh blood samples (within $6 \mathrm{~h}$ ) and $\mathrm{CHr}$ is time sensitive due to the maturation of erythrocytes [42].

Hepcidin, given its central role in iron metabolism regulation, has been evaluated as a biomarker of iron status and iron responsiveness in CKD patients. Many studies 
have confirmed increased hepcidin levels in CKD patients [67-69] Serum hepcidin levels have the strongest correlation with serum ferritin, TSAT and sTfR [67, 70-72] and are influenced by inflammation $[67,72,73]$ iron and ESA administration $[67,71,72,74]$ and dialysis clearance $[68$, $69,75]$. Due to a significant intra-individual variability, the short-term measurement of serum hepcidin is not useful as a biomarker of iron status in CKD patients [76, 77]. And the interpretation of the serum hepcidin level must take into account all confounding factors. Hepcidin is not a good predictor of the response to iron supplementation in dialysis [57] and non-dialysis-dependent patients [78].

Soluble hemojuvelin (sHJV) has been explored as biomarker of iron status in patients without [79], and with chronic kidney disease [80, 81]. Opposite to cell surface HJV, soluble HJV may act as an inhibitor of BMP signaling and restrain hepcidin expression [82]. Some studies revealed that sHJV may be increased in iron deficiency and decreased during iron administration [82-84], suggesting that sHJV may be a diagnostic marker of iron status. One important concern in soluble HJV assessment is assay validity $[81,82$, 85], and future studies are needed to establish sHJV value as biomarker of iron status and response to therapy.

Growth differentiation factor 15 (GDF15), secreted by matured erythroblasts, is involved in hepcidin metabolism and as such is potentially involved in iron metabolism [86]. However, available data on the role of GDF15 as the marker of iron status are scarce. In fact, one study suggested that GDF15 is increased in iron deficiency [87]; the other did not confirm it [88]. Moreover, serum GDF15 levels may be influenced by kidney disease, malnutrition and inflammation [89] complicating its usefulness as an iron status biomarker.

Plasma neutrophil gelatinase-associated lipocalin (NGAL) is known as a predictor of kidney disease progression and marker of inflammation [90, 91]. In addition, NGAL influences iron sequestration; however, the way that NGAL influences the iron balance depends on its form. The bound form of NGAL decreases and free form of NGAL increases the level of serum iron. Few studies evaluated the usefulness of NGAL as a biomarker of iron stores in CKD patients, suggesting its good specificity and sensitivity in the detection of decreased iron stores [92, 93]; however, future studies are needed to establish the role as a biomarker of iron status.

In summary, we conducted a search in Medline, PubMed, and Embase using the keywords: iron, biomarkers, kidney failure, CKD, dialysis, hemodialysis, peritoneal dialysis. As described in the Preferred Reporting Items for Systematic reviews and Meta-Analyses (PRISMA) group [94]. We limited our search to adult patients and publications in English and Polish till 2020. We found 541 articles, but only 102 articles were analyzed due to lack of information about full data, and availability of abstracts only or duplication. The available data were very limited due to a high degree of heterogeneity. Taking into account the drawbacks and sometimes limited data on the utility of alternative biomarkers of iron status in chronic kidney disease, the traditional biomarkers still remain the hallmarks of the assessment of iron metabolism and responsiveness to iron therapy in this patient population.

\section{Therapeutic strategies}

Therapeutic approach should begin with diagnosis and elimination of the underlying condition responsible for iron deficiency. Iron supplementation is the next step. Initiation of iron in CKD patients with anemia should be based on preexisting iron stores and the target $\mathrm{Hb}$ level that is desired. Even though oral iron is generally considered sufficient in CKD patients not on dialysis and PD patients, intravenous form is the preferred route, especially in hemodialysis patients. Oral iron is associated with poor intestinal absorption and adverse event-related (mainly gastrointestinal) low adherence to therapy [94]. It needs to be emphasized that the goal of treatment with iron is not to increase Hb levels to the normal range but to reduce the risk of development of severe anemia and associated complications and to minimize the need for blood transfusions [4]. ESA therapy is generally initiated in ESRD patients with replete iron stores (i.e. TSAT $>30 \%$ and/or ferritin $>500 \mathrm{mcg} / \mathrm{l}$ ) whose Hb levels are below $10 \mathrm{~g} / \mathrm{dl}$ [95]. Failure to increase $\mathrm{Hb}$ concentration after the first month of ESA treatment is defined by KDIGO as ESA hyporesponsiveness-a poor prognostic factor in terms of patient mortality [36]. There are several factors responsible for ESA hyporesponsiveness-one of them is inflammation. A new group of oral agents known as HIF prolyl hydroxylase-inhibitors has been developed to improve CKD-associated anemia. The beneficial effect of HIF stabilizers on hemoglobin levels has been observed regardless of the patient's iron stores and inflammatory status [17]. However, the long-term safety of these novel agents, especially regarding potential risk of tumorigenesis and worsening of proliferative diabetic retinopathy, has yet to be established $[17,96]$. Additionally, the increased usage of intravenous iron in hemodialysis patients during recent years has led to increasing concern over the potential development of iron overload [97, 98]. Recently, we reported that a substantial number of hemodialysis patients have positive labile plasma iron after intravenous iron administration, which positively correlated with laboratory parameters that are currently in routine clinical use for detecting iron overload and with higher intravenous iron dose [99]. Thus, we suggest to perform further studies to establish the clinical implications of labile plasma iron, a component of nontransferrin-bound 
iron which may be a more accurate indicator of impending iron overload monitoring in hemodialysis patients.

\section{Conclusion}

CKD patients tend to have subclinical inflammatory-related immune activation. The pathogenesis of chronic inflammation in CKD is still not fully understood, yet the proposed underlying factors include oxidative stress, cellular senescence, hypoxia, exogenous factors (such as dialyzer membrane or central venous catheter), immune dysfunction, gut dysbiosis and retention of uremic toxins [100]. Inflammatory blockade is associated with resistance to erythropoietin despite iron availability, which is more clearly understood now that the role of hepcidin in iron metabolism has been identified. Studies conducted so far revealed that serum ERFE concentration increases in response to ESA treatment in CKD patients, while the correlation between ERFE and hepcidin remains unclear [101]. Despite having classical iron biomarkers, we still looking for new ones to improve our diagnostic and predictive tools. There is an area of uncertainty regarding diagnostic utility of both ERFE and hepcidin in ESRD patients [102]. Higher concentration of hepcidin in oligoanuric patients may reflect decreased renal clearance. Furthermore, the hepcidin-lowering effect of ERFE in ESRD patients treated with ESAs may be blunted by underlying inflammation and concomitant iron treatment. Up to date, we have no cost-effective analytical tests to assess iron metabolism in patients with CKD. Therefore, future studies should validate the use of ERFE as a biomarker of erythropoiesis and predictor of response to iron and ESA therapy in dialysis-dependent patients.

Open Access This article is licensed under a Creative Commons Attribution 4.0 International License, which permits use, sharing, adaptation, distribution and reproduction in any medium or format, as long as you give appropriate credit to the original author(s) and the source, provide a link to the Creative Commons licence, and indicate if changes were made. The images or other third party material in this article are included in the article's Creative Commons licence, unless indicated otherwise in a credit line to the material. If material is not included in the article's Creative Commons licence and your intended use is not permitted by statutory regulation or exceeds the permitted use, you will need to obtain permission directly from the copyright holder. To view a copy of this licence, visit http://creativecommons.org/licenses/by/4.0/.

\section{References}

1. Blanc B, Finch CA, Hallberg L, Herbert V, Lawkowicz W, Layrisse M, Mollin DL, Rachmilewitz M, Ramalingaswami V, Sanchez-Medal L, Vintrobe MM (1968) Nutritional anemias. Report of a WHO Scientific Group. WHO Tech Rep Ser 405:140. https://apps.who.int/iris/bitstream/handle/10665/40707/
WHO_TRS_405.pdf; jsessionid $=723826504327390$ B6E2B ACE6A264BC23? sequence $=1$

2. Astor BC, Muntner P, Levin A, Eustace JA, Coresh J (2002) Association of kidney function with anemia, the Third National Health and Nutrition Examination Survey (1988-1994). Arch Intern Med 162(12):1401-1408

3. Sofue T, Nakagawa N, Kanda E, Nagasu H, Matsushita K, Nangaku M, Maruyama S, Wada T, Terada Y, Yamagata K, Narita I, Yanagita M, Sugiyama H, Shigematsu T, Ito T, Tamura K, Isaka Y, Okada H, Tsuruya K, Yokoyama H, Nakashima N, Hiromi K, Ohe K, Okada M, Kashihara N (2020) Prevalence of anemia in patients with chronic kidney disease in Japan: a nationwide, cross-sectional cohort study using data from the Japan Chronic Kidney Disease Database (J-CKD-DB). PLoS ONE 15(7):e0236132. https://doi.org/10.1371/journal.pone.0236132

4. Babitt JL, Lin HY (2012) Mechanisms of anemia in CKD. JASN 23(10):1631-1634. https://doi.org/10.1681/ASN.20111 11078

5. Fishbane S, Spinowitz B (2018) Update on anemia in ESRD and earlier Stages of CKD: core curriculum. Am J Kidney Dis 71(3):423-435. https://doi.org/10.1053/j.ajkd.2017.09.026

6. Filipczyk L, Król P, Wystrychowski A (2010) Hepcydynahormon wątrobowy kontrolujący gospodarkę żelaza. Forum Nefrologiczne 3(4):233-242. https://journals.viamedica.pl/ forum_nefrologiczne/article/view/10359

7. Mazur G, Wróbel T, Nosol J (2005) Rola hepcydyny w regulacji homeostazy żelaza. Acta Haematologica Polonica 36(2):167-175. https://pthit.pl/Acta_Haematologica_Polon ica,Hepcydyna_Hemochromatoza_Niedokrwistosc_w_przeb iegu_chorob_przewleklych,250.html

8. Andrews NC (2008) Forging a field: the golden age iron biology. Blood 112(2):219-230. https://doi.org/10.1182/blood $-2007-12-077388$

9. Beaumont C, Delaby C (2009) Recycling iron in normal and pathological states. Semin Hematol 46(4):328-338. https://doi. org/10.1053/j.seminhematol.2009.06.004

10. Lipiński P, Starzyński R (2004) Regulacja ogólnoustrojowej homeostazy żelaza przez hepcydynę. Postępy Hig Med Dosw (online) 58:65-73. https://www.phmd.pl/api/files/view/1702. pdf

11. Park CH, Valore EV, Waring AJ, Ganz T (2001) Hepcidin, a urinary antimicrobial peptide synthesized in the liver. J Biol Chem 276(11):7806-7810. https://doi.org/10.1074/jbc.m008922200

12. Camaschella C (2015) Iron-deficiency anemia. N Engl J Med 372:1832-1843. https://doi.org/10.1056/NEJMra1401038

13. Fleming RE, Ponka $P$ (2012) Iron overload in human disease. $N$ Engl J Med 366:348-359. https://doi.org/10.1056/NEJMra1004 967

14. Casu C, Nemeth E, Rivella S (2018) Hepcidin agonists as therapeutic tools. Blood 131(16):1790-1794. https://doi.org/10.1182/ blood-2017-11-737411

15. Zhang A-S, Enns CA (2009) Molecular mechanisms of normal iron homeostasis. Hematology Am Soc Hematol Educ Program 2009:207-214. https://doi.org/10.1182/asheducation-2009.1.207

16. Hanudel MR, Rappaport M, Chua K, Gabayan V, Qiao B, Jung G, Salusky IB, Ganz T, Nemeth E (2018) Levels of the erythropoietin-responsive hormone erythroferrone in mice and humans with chronic kidney disease. Haematologica 103(4):e141-e142. https://doi.org/10.3324/haematol.2017.181743

17. Hasegawa T, Koiwa F, Akizawa T (2018) Anemia in conventional hemodialysis: finding the optimal treatment balance. Semin Dial 31(6):599-606. https://doi.org/10.1111/sdi.12719

18. Peyssonnaux C, Zinkernagel AS, Schuepbach RA, Rankin E, Vaulont S, Haase VH, Nizet V, Johnson RS (2007) Regulation of iron homeostasis by the hypoxia-inducible transcription factors 
(HIFs). J Clin Invest 117(7):1926-1932. https://doi.org/10.1172/ jci31370

19. Ueda N, Takasawa K (2018) Impact of inflammation on ferritin, hepcidin and the management of iron deficiency anemia in chronic kidney disease. Nutrients 10(9):1173. https://doi. org/10.3390/nu10091173

20. Parker BD, Schurgers LJ, Brandenburg VM, Christenson RH, Vermeer C, Ketteler M et al (2010) The associations of fibroblast growth factor 23 and uncarboxylated matrix Gla protein with mortality in coronary artery disease: the Heart and Soul Study. Ann Intern Med 152(10):640-648. https://doi.org/10.7326/00034819-152-10-201005180-00004

21. Khan AM, Chirinos JA, Litt H, Yang W, Rosas SE (2012) FGF-23 and the progression of coronary arterial calcification in patients new to dialysis. Clin J Am Soc Nephrol 7(12):20172022. https://doi.org/10.2215/cjn.02160212

22. Faul C, Amaral AP, Oskouei B, Hu MC, Sloan A, Isakova T et al (2011) FGF23 induces left ventricular hypertrophy. J Clin Invest 121(11):4393-4408. https://doi.org/10.1172/jci46122

23. Mendoza MJ, Isakova T, Ricardo AC, Xie H, Navaneethan SD, Anderson AH et al (2012) Fibroblast growth factor 23 and inflammation in CKD. Clin J Am Soc Nephrol 7(7):1155-1162. https://doi.org/10.2215/cjn.13281211

24. Wolf M, White KE (2014) Coupling fibroblast growth factor 23 production and cleavage: iron deficiency, rickets, and kidney disease. Curr Opin Nephrol Hypertens 23(4):411-419. https://doi. org/10.1097/01.mnh.0000447020.74593.6f

25. Braithwaite V, Prentice AM, Doherty C, Prentice A (2012) FGF23 is correlated with iron status but not with inflammation and decreases after iron supplementation: a supplementation study. Int J Pediatr Endocrinol 2012(1):27. https://doi. org/10.1186/1687-9856-2012-27

26. Deger SM, Erten Y, Pasaoglu OT, Derici UB, Reis KA, Onec K, Pasaoglu H (2013) The effects of iron on FGF23-mediated Ca-P metabolism in CKD patients. Clin Exp Nephrol 17(3):416-423. https://doi.org/10.1007/s10157-012-0725-0

27. Nemeth E, Valore E, Territo M, Schiller G, Lichtenstein A, Ganz $\mathrm{T}$ (2003) Hepcidin, a putative mediator of anemia of inflammation, is a type II acute phase protein. Blood 101(7):2461-2463. https://doi.org/10.1182/blood-2002-10-3235

28. Wrighting DM, Andrews NC (2006) Interleukin-6 induces hepcidin expression through STAT3. Blood 108(9):3204-3209. https ://doi.org/10.1182/blood-2006-06-027631

29. Nicolas G, Bennoun M, Porteu A, Mativet S, Beaumont C, Grandchamp B, Sirito M, Sawadogo M, Kahn A, Vaulont S (2002) Severe iron deficiency anemia in transgenic mice expressing liver hepcidin. Proc Natl Acad Sci USA 99(7):4596-4601. https://doi.org/10.1073/pnas.072632499

30. Donderski R, Kardymowicz A, Manitius J (2009) Niedokrwistość nerkopochodna. Wybrane aspekty diagnostyki i terapii. Choroby Serca i Naczyń 6(2):82-93. https://journals.viamedica.pl/choro by_serca_i_naczyn/article/view/12052/9930

31. Ganz T, Nemeth E (2016) Iron balance and the role of hepcidin in chronic kidney disease. Semin Nephrol 36:87-93. https://doi. org/10.1016/j.semnephrol.2016.02.001

32. Fasano A (2012) Leaky gut and autoimmune diseases. Clin Rev Allergy Immunol 42(1):71-78. https://doi.org/10.1007/s1201 6-011-8291-x

33. Babitt JL, Lin HY (2012) Mechanism of anemia in CKD. J Am Soc Nephrol 23(10):1631-1634. https://doi.org/10.1681/ ASN.2011111078

34. Wish JB (2006) Assessing iron status: beyond serum ferritin and transferrin saturation. Clin J Am Soc Nephrol 1(suppl 1):S4-S8. https://doi.org/10.1159/000486968
35. Lopez A, Cacoub P, Macdougall IC, Peyrin-Biroulet L (2016) Iron deficiency anaemia. Lancet 387:907-916. https://doi. org/10.1016/S0140-6736(15)60865-0

36. The Kidney Disease: Improving Global Outcomes (KDIGO) Anemia Work Group (2012) KDIGO clinical practice guideline for anemia in chronic kidney disease. Kidney Int Suppl 2:279335. https://doi.org/10.1038/kisup.2012.37

37. National Kidney Foundation (2006) KDOQI clinical practice guidelines and clinical practice recommendations for anemia in chronic kidney disease. Am J Kidney Dis 47(5 Suppl 3):S11S145. https://doi.org/10.1053/j.ajkd.2006.03.010

38. Locatelli F, Bárány P, Covic A, De Francisco A, Del Vecchio L, Goldsmith D, Hörl W, London G, Vanholder R, Van Biesen W, ERA-EDTA ERBP Advisory Board (2013) Kidney disease: improving global outcomes guidelines on anaemia management in chronic kidney disease: a European Renal Best Practice position statement. Nephrol Dial Transplant 28:1346-1359. https:// doi.org/10.1093/ndt/gft033

39. Tsubakihara Y, Nishi S, Akiba T, Hirakata H, Iseki K, Kubota M, Kuriyama S, Komatsu Y, Suzuki M, Nakai S, Hattori M, Babazono T, Hiramatsu M, Yamamoto H, Bessho M, Akizawa T (2010) 2008 Japanese Society for Dialysis Therapy: guidelines for renal anemia in chronic kidney disease. Ther Apher Dial 14:240-275. https://doi.org/10.111 1/j.1744-9987.2010.00836.x

40. Macginley R, Walker R, Irving M (2013) KHA-CARI guideline: use of iron in chronic kidney disease patients. Nephrology (Carlton) 18:747-749. https://doi.org/10.1111/nep.12139

41. Stancu S, Stanciu A, Zugravu A, Bârsan L, Dumitru D, Lipan M, Mircescu G (2010) Bone marrow iron, iron indices, and the response to intravenous iron in patients with non-dialysisdependent CKD. Am J Kidney Dis 55:639-647. https://doi. org/10.1053/j.ajkd.2009.10.043

42. Gaweda AE (2017) Markers of iron status in chronic kidney disease. Hemodial Int 21(Suppl 1):S21-S27. https://doi. org/10.1111/hdi.12556

43. Wish JB (2006) Assessing iron status: beyond serum ferritin and transferrin saturation. Clin J Am Soc Nephrol 1(Suppl 1):S4-S8. https://doi.org/10.2215/CJN.01490506

44. Besarab A, Coyne DW (2010) Iron supplementation to treat anemia in patients with chronic kidney disease. Nat Rev Nephrol 6:699-771. https://doi.org/10.1038/nrneph.2010.139

45. Hayes M (2019) Measurement of iron status in chronic kidney disease. Pediatr Nephrol 34:605-613. https://doi.org/10.1007/ s00467-018-3955-x

46. Wong MMY, Tu C, Li Y, Pecoits-Filho R, Lopes AA, Narita I, Reichel H, Port FK, Sukul N, Stengel B, Robinson BM, Massy ZA, Pisoni RL, the CKDopps Investigators (2019) Anemia and iron deficiency among chronic kidney disease Stages 3-5ND patients in the Chronic Kidney Disease Outcomes and Practice Patterns Study: often unmeasured, variably treated. Clin Kidney J 13:613-624. https://doi.org/10.1093/ckj/sfz091

47. Fishbane S, Pollack S, Feldman HI, Joffe MM (2009) Iron indices in chronic kidney disease in the National Health and Nutritional Examination Survey 1988-2004. Clin J Am Soc Nephrol 4:57-61. https://doi.org/10.2215/CJN.01670408

48. Besarab A, Drueke TB (2020) The problem with trasferrin saturation as an indicator of iron "sufficiency" in chronic kidney disease. Nephrol Dial Transplant. https://doi.org/10.1093/ndt/gfaa0 48

49. Kim T, Rhee CM, Streja E, Obi Y, Brunelli SM, Kovesdy CP, Kalantar-Zadeh K (2017) Longitudinal trends in serum ferritin levels and associated factors in a national incident hemodialysis cohort. Nephrol Dial Transplant 32:370-377. https://doi. org/10.1093/ndt/gfw012 
50. Kalantar-Zadeh K, Rodriguez RA, Humphreys MH (2004) Association between serum ferritin and measures of inflammation, nutrition and iron in haemodialysis patients. Naphrol Dial Transplant 19:141-149. https://doi.org/10.1093/ndt/gfg493

51. Ruiz-Jaramillo Mde L, Guizar-Mendoza JM, Amador-Licona N, de Jesus G-N, Hernández-González MA, Dubey-Ortega LA, Solorio-Meza SE (2011) Iron overload as cardiovascular risk factor in children and adolescents with renal disease. Nephrol Dial Transplant 26:3268-3273. https://doi.org/10.1093/ndt/gfr044

52. Macdougall IC, Bock AH, Carrera F, Eckardt KU, Gaillard C, Van Wyck D, Roubert B, Cushway T, Roger SD, FIND-CKD Study Investigators (2014) FIND-CKD: a randomized trial of intravenous ferric carboxymaltose versus oral iron in patients with chronic kidney disease and iron deficiency anaemia. Nephrol Dial Transplant 29:2075-2084. https://doi.org/10.1093/ndt/ gfu201

53. Macdougall IC, Bock AH, Carrera F, Eckardt KU, Gaillard C, Van Wyck D, Meier Y, Larroque S, Perrin A, Roger SD (2017) Erythropoietic response to oral iron in patients with non-dialysis-dependent chronic kidney disease in FIND-CKD trial. Clin Nephrol 88:301-310. https://doi.org/10.5414/cn109198

54. Takasawa K, Takeda C, Wada T, Ueda N (2018) Optimal serum ferritin levels for iron deficiency anemia during oral iron therapy (OIT) in Japanese hemodialysis patients with minor inflammation and benefit of intravenous iron therapy for OIT-nonresponders. Nutrients 10:428. https://doi.org/10.3390/nu10040428

55. Singh AK, Coyne DW, Shapiro W, Rizkala AR, the DRIVE Study Group (2007) Predictors of the response to treatment in anemic hemodialysis patients with high serum ferritin and low transferrin saturation. Kidney Int 71:1163-1171. https://doi. org/10.1038/sj.ki.5002223

56. Musanovic A, Trnacevic S, Mekic M, Musanovic A (2013) The influence of inflammatory markers and CRP predictive value in relation to target hemoglobin level in patients on chronic hemodialysis. Med Arch 67:361-364. https://doi.org/10.5455/medar h.2013.67.361-364

57. Tessitore N, Girelli D, Campostrini N, Bedogna V, Solero GP, Castagna A, Melilli E, Mantovani W, De Matteis G, Olivieri O, Poli A, Lupo A (2010) Hepcidin is not useful as a biomarker for iron needs in haemodialysis patients on maintenance erythropoiesis-stimulating agents. Nephrol Dial Transplant 25:3996-4002. https://doi.org/10.1093/ndt/gfq321

58. Suchdev PS, Williams AM, Mei Z, Flores-Ayala R, Pasricha SR, Rogers LM, Ml NS (1633S) Assessment of iron status in settings of inflammation: challenges and potential approaches. Am J Clin Nutr 106(Suppl 6):1626S-1633S. https://doi.org/10.3945/ ajcn.117.155937

59. Tarng DC, Huang TP (2002) Determinants of circulating soluble transferrin receptor level in chronic haemodialysis patients. Nephrol Dial Transplant 17:1063-1069. https://doi.org/10.1093/ ndt/17.6.1063

60. Chiang WC, Tsai TJ, Chen YM, Lin SL, Hsieh BS (2002) Serum soluble transferrin receptor reflects erythropoiesis but not iron availability in erythropoietin-treated chronic hemodialysis patients. Clin Nephrol 58:363-369. https://doi.org/10.5414/ cnp58363

61. Chen YC, Hung SC, Tarng DC (2006) Association between transferrin receptor-ferritin index and conventional measures of iron responsiveness in hemodialysis patients. Am Kidney Dis 47:1036-1044. https://doi.org/10.1053/j.ajkd.2006.02.180

62. Hackeng CM, Beerenhout CM, Hermans M, Van der Kuy PHM, Van der Dussen H, Van Dieijen-Visser MP, Hamulyák K, Van der Sande FM, Leunissen KM, Koomanal JP (2004) The relationship between reticulocyte hemoglobin content with C-reactive protein and conventional iron parameters in dialysis patients. J Nephrol $17: 107-111$
63. Bovy C, Tsobo C, Crapanzano L, Rorive G, Beguin Y, Albert A, Paulus JM (1999) Factors determining the percentage of hypochromic red blood cells in hemodialysis patients. Kidney Int 56:1113-1119. https://doi.org/10.1046/j.1523-1755.1999.00627 .x

64. Tessitore N, Solero GP, Lippi G, Bassi A, Faccini GB, Bedogna V, Gammaro L, Brocco G, Restivo G, Bernich P, Lupo A, Maschio G (2001) The role of iron status markers in predicting response to intravenous iron in haemodialysis patients on maintenance erythropoietin. Nephrol Dial Transplant 16:1416-1423. https://doi.org/10.1093/ndt/16.7.1416

65. Ratcliffe LE, Thomas W, Glen J, Padhi S, Pordes BAJ, Wonderling D, Connell R, Stephens S, Mikhail AI, Fogarty DG, Cooper JK, Dring B, Devonald MAJ, Brown C, Thomas ME (2016) Diagnosis and management of iron deficiency in CKD: a summary of the NICE guideline recommendations and their rationale. Am J Kidney Dis 67:548-558. https://doi.org/10.1053/j. ajkd.2015.11.012

66. Chung M, Moorthy D, Hadar N, Salvi P, Iovin RC, Lau J (2012) Biomarkers for assessing and managing iron deficiency anemia in late-stage chronic kidney disease. Agency for Healthcare Research and Quality, Rockville. Report No.: 12(13)-EHC140-EF

67. Zaritsky J, Young B, Wang HJ, Westerman M, Olbina G, Nemeth E, Ganz T, Rivera S, Nissenson AR, Salusky IB (2009) Hepcidin-a potential novel biomarker for iron status in chronic kidney disease. Clin J Am Soc Nephrol 4:1051-1056. https://doi. org/10.2215/CJN.05931108

68. Malyszko J, Malyszko JS, Kozminski P, Mysliwiec M (2009) Type of renal replacement therapy and residual renal function may affect prohepcidin and hepcidin. Ren Fail 31:876-883. https ://doi.org/10.3109/08860220903216071

69. Zaritsky J, Young B, Gales B, Wang HJ, Rastogi A, Westerman M, Nemeth E, Ganz T, Salusky IB (2010) Reduction of serum hepcidin by hemodialysis in pediatric and adult patients. Clin J Am Soc Nephrol 5:1010-1014. https://doi.org/10.2215/ CJN.08161109

70. van der Weerd NC, Grooteman MP, Bots ML, van den Dorpel MA, Den Hoedt CH, Mazairac Albert HA, Nubé MJ, Lars Penne E, Gaillard CA, Wetzels JFM, Wiegerinck ET, Swinkels DW, Blankestijn PJ, ter Wee PM, CONTRAST investigator (2012) Hepcidin-25 in chronic hemodialysis patients is related to residual kidney function and not to treatment with erythropoiesis stimulating agents. PLoS ONE 7:e39783. https://doi. org/10.1371/journal.pone.0039783

71. Ashby DR, Gale DP, Busbridge M, Murphy KG, Duncan ND, Cairns TD, Taube DH, Bloom SR, Tam FW, Chapman RS, Maxwell PH, Choi P (2009) Plasma hepcidin levels are elevated but responsive to erythropoietin therapy in renal disease. Kidney Int 75:976-981. https://doi.org/10.1038/ki.2009.21

72. Mercadal L, Metzger M, Haymann JP, Thervet E, Boffa JJ, Flamant M, Vrtovsnik F, Houillier P, Froissart M, Stengel B (2014) The relation of hepcidin to iron disorders, inflammation and hemoglobin in chronic kidney disease. PLoS ONE 9:e99781. https://doi.org/10.1371/journal.pone.0099781

73. Łukaszyk E, Łukaszyk M, Koc-Żórawska E, Tobolczyk J, Bodzenta-Łukaszyk A, Małyszko J (2015) Iron status and inflammation in early stages of chronic kidney disease. Kidney Blood Press Res 40:366-373. https://doi.org/10.1159/000368512

74. Kato A, Tsuji T, Luo J, Sakao Y, Yasuda H, Hishida A (2008) Association of prohepcidin and hepcidin-25 with erythropoietin response and ferritin in hemodialysis patients. Am J Nephrol 28:115-121. https://doi.org/10.1159/000109968

75. Stefánsson BV, Abramson M, Nilsson U, Haraldsson B (2012) Hemodiafiltration improve plasma 25-hepcidin levels: a prospective, randomized, blinded, cross-over study comparing 
hemodialysis and hemodiafiltration. Nephron Extra 2:55-65. https://doi.org/10.1159/000336482

76. Ford BA, Eby CS, Scott MG, Coyne Daniel W (2010) Intra-individual variability of serum hepcidin precludes its use as a marker of iron status in hemodialysis patients. Kidney Int 78:769-773. https://doi.org/10.1038/ki.2010.254

77. Peters HP, Rumjon A, Bansal SS, Laarakkers Coby MM, van den Brand JAJG, Sarafidis P, Musto R, Malyszko J, Swinkels DW, Wetzels JFM, Macdougall IC (2012) Intra-individual variability of serum hepcidin-25 in haemodialysis patients using mass spectrometry and ELISA. Nephrol Dial Transplant 27:3923-3929. https://doi.org/10.1093/ndt/gfs164

78. Gaillard CA, Bock AH, Carrera F, Eckardt KU, Van Wyck DB, Bansal SS, Cronin M, Meier Y, Larroque S, Roger SD, Macdougall IC (2016) Hepcidin response to iron therapy in patients with non-dialysis dependent CKD: an analysis of the FIND-CKD trial. PLoS ONE 11:e0157063. https://doi.org/10.1371/journ al.pone. 0157063

79. Finkenstedt A, Widschwendter A, Brasse-Lagnel CG, Theurl I, Hubalek M, Dieplinger H, Tselepis C, Ward DG, Vogel W, Zoller H (2012) Hepcidin is correlated to soluble hemojuvelin but not increased GDF15 during pregnancy. Blood Cells Mol Dis 48:233-237. https://doi.org/10.1016/j.bcmd.2012.02.001

80. Malyszko J, Malyszko JS, Levin-Iaina N, Koc-Zorawska E, Kozminski P, Mysliwiec M (2011) Is hemojuvelin a possible new player in iron metabolism in hemodialysis patients? Int Urol Nephrol 44:1805-1811. https://doi.org/10.1007/s1125 5-011-0084-x

81. Rumjon A, Sarafidis P, Brincat S, Musto R, Malyszko J, Bansal SS, Macdougall IC (2012) Serum hemojuvelin and hepcidin levels in chronic kidney disease. Am J Nephrol 35:295-304. https:// doi.org/10.1159/000336528

82. Lin L, Goldberg YP, Ganz T (2005) Competitive regulation of hepcidin mRNA by soluble and cell-associated hemojuvelin. Blood 106:2884-2889. https://doi.org/10.1182/blood -2005-05-1845

83. Silvestri L, Pagani A, Camaschella C (2008) Furin-mediated release of soluble hemojuvelin: a new link between hypoxia and iron homeostasis. Blood 111:924-931. https://doi.org/10.1182/ blood-2007-07-100677

84. Zhang AS, Anderson SA, Meyers KR, Hernandez C, Eisenstein RS, Enns CA (2007) Evidence that inhibition of hemojuvelin shedding in response to iron is mediated through neogenin. J Biol Chem 282:12547-12556. https://doi.org/10.1074/jbc.M6087 88200

85. Gutièrrez OM, Sun CC, Chen W, Babitt JL, Lin HY (2012) Statement of concern about a commercial assay used to measure soluble hemojuvelin in humans. Am J Nephrol 36:332-333. https:// doi.org/10.1159/000342519

86. Malyszko J, Koc-Żórawska E, Levin-Iaina N, Małyszko J, Koźmiński P, Kobus G, Myśliwiec M (2012) New parameters in iron metabolism and functional iron deficiency in patients on maintenance hemodialysis. Pol Arch Med Wewn 122:537-542

87. Lakhal S, Talbot NP, Crosby A, Stoepker C, Townsend ARM, Robbins PA, Pugh CW, Ratcliffe PJ, Mole DR (2009) Regulation of growth differentiation factor 15 by intracellular iron. Blood 113:1555-1536. https://doi.org/10.1182/blood-2008-07-170431

88. Theurl I, Finkelstedt A, Schroll A, Nairz M, Sonnweber T, Bellmann-Weiler R, Theurl M, Seifert M, Wroblewski VJ, Murphy AT, Witcher D, Zoller H, Weiss G (2010) Growth differentiation factor in anaemia of chronic disease, iron deficiency anaemia and mixed type anaemia. Br J Hematol 148:449-455. https://doi.org/ 10.1111/j.1365-2141.2009.07961.x

89. Breit SN, Carrero JJ, Tsai VW, Yagoutifam N, Luo W, Kuffner T, Bauskin AR, Wu L, Jiang L, Barany P, Heimburger O, Murikami MA, Apple FS, Marquis CP, Macia L, Lin S, Sainsbury A,
Herzog H, Law M, Stenvinkel P, Brown DA (2012) Macrophage inhibitory cytokine-1 (MIC-1/GDF15) and mortality in endstage renal disease. Nephrol Dial Transplant 27:70-75. https:// doi.org/10.1093/ndt/gfr575

90. Bolignano D, Lacquaniti A, Coppolino G, Donato V, Campo S, Fazio MR, Nicocia G, Buemi M (2009) Neutrophil gelatinase-associated lipocalin (NGAL) and progression of chronic kidney disease. Clin J Am Soc Nephrol 4:337-344. https://doi. org/10.2215/CJN.03530708

91. Castillo-Rodriguez E, Fernandez-Prado R, Martin-Cleary C, Pizarro-Sánchez MS, Sanchez-Niño MD, Sanz AB, FernandezFernandez B, Ortiz A (2017) Kidney injury marker 1 and neutrophil gelatinase-associated lipocalin in chronic kidney disease. Nephron 136:263-267. https://doi.org/10.1159/000447649

92. Kim IY, Kim JH, Lee DW, Lee SB, Rhee H, Song SH, Seong EY, Kwak IS (2018) Plasma neutrophil gelatinase-associated lipocalin is associated with iron status in anemic patients with predialysis chronic kidney disease. Clin Exp Nephrol 22:28-34. https://doi.org/10.1007/s10157-017-1409-6

93. Avci Cicek E, Rota S, Dursun B, Cavalci E (2016) Evaluation of serum NGAL and hepcidin levels in chronic kidney disease patients. Ren Fail 38:35-39. https://doi.org/10.3109/08860 22X.2015.1107823

94. Moher D, Liberati A, Tetzlaff J, Altman DG (2009) Preferred reporting items for systematic reviews and meta-analyses: the PRISMA statement. PLoS Med 6:e1000097. https://doi. org/10.1371/journal.pmed.1000097

95. Cappellini MD, Comin-Colet J, De Francisco A, Dignass A, Doehner W, Lam CS, Macdougall IC, Rogler G, Camaschella C, Kadir R, Kassebaum NJ, Spahn DR, Taher AT, Musallam KM, IRON CORE Group (2017) Iron deficiency across chronic inflammatory conditions: international expert opinion o definition, diagnosis and management. Am J Hematol 92(10):10681078. https://doi.org/10.1002/ajh.24820

96. Malyszko J, Malyszko JS, Matuszkiewicz-Rowinska J (2019) Hepcidin as a therapeutic target for anemia and inflammation associated with chronic kidney disease. Expert Opin Ther Targets 23(5):407-421. https://doi.org/10.1080/14728222.2019.1599358

97. Wish JB, Aronoff GR, Bacon BR, Brugnara C, Eckardt KU, Ganz T, Macdougall IC, Núñez J, Perahia AJ, Wood JC (2018) Positive iron balance in chronic kidney disease: how much is too much and how to tell? Am J Nephrol 47(2):72-83. https://doi. org/10.1159/000486968

98. Nakanishi T, Kuragano T (2020) Potential hazards of recent trends in liberal iron use for renal anemia. Clin Kidney J. https:// doi.org/10.1093/ckj/sfaa117

99. Lenihan CR, Winkelmayer WC (2016) The dawning of a new day in CKD anemia care? J Am Soc Nephrol 27(4):968-970. https:// doi.org/10.1681/ASN.2015091009

100. Bnaya A, Shavit L, Malyszko JS, Malyszko J, Slotki I (2020) Labile plasma iron levels in chronic hemodialysis patients treated by intravenous iron supplementation. Ther Apher Dial 24(4):416-422. https://doi.org/10.1111/1744-9987.13458

101. Cobo G, Lindholm B, Stenvinkel P (2018) Chronic inflammation in end-stage renal disease and dialysis. Nephrol Dial Transplant 33(suppl 3):iii35-iii40

102. Appleby S, Chew-Harris J, Troughton RW, Richards AM, Pemberton CJ (2020) Analytical and biological assessment of circulating human erythroferrone. Clin Biochem 79:41-47. https:// doi.org/10.1016/j.clinbiochem.2020.02.001

Publisher's Note Springer Nature remains neutral with regard to jurisdictional claims in published maps and institutional affiliations. 